\title{
A Study on Task Commitment in Coaching Systems, Academic Culture, and Learning Organizations
}

\author{
Ansori1 \\ DOI: 10.35445/alishlah.v13i3.1435
}

\begin{abstract}
Article Info
Abstract

Keywords: Coaching System;

Learning Organization; Academic Culture and Task Commitment

This study aims to determine the effect of coaching systems, learning organizations, and academic culture on task commitment. A survey and path analysis technique was used in the study. The study was conducted in an education institution (Indonesian Navy) using a proportional random sample of 52 lecturers. The data analysis revealed a direct correlation between task commitment, coaching system, learning organization, and academic culture. Finally, the study concludes that the coaching system's impact and the learning organization's influence on task commitment are critical. As a result, it is recommended that some programs be developed to strengthen the coaching system and learning organization.
\end{abstract}

Kata kunci:

Sistem Pembinaan;

Organisasi

Pembelajaran;

Budaya Akademik dan

Komitmen Tugas

\begin{abstract}
Abstrak
Penelitian ini bertujuan untuk mempelajari pengaruh sistem pembinaan, organisasi pembelajaran, dan budaya akademik terhadap komitmen tugas: penelitian ini menggunakan metode survei dan teknik analisis jalur. Penelitian dilakukan di Lembaga Pendidikan (Angkatan Laut) dengan sampel sebanyak 52 orang dosen yang diambil secara proporsional secara acak. Analisis data menunjukkan bahwa terdapat pengaruh langsung sistem pembinaan, organisasi pembelajaran, dan budaya akademik terhadap komitmen tugas. Akhirnya, studi menyimpulkan bahwa dampak dari sistem pembinaan dan organisasi pembelajaran merupakan faktor penting untuk mempengaruhi komitmen tugas. Oleh karena itu, disarankan untuk menyiapkan beberapa program yang dapat meningkatkan sistem pembinaan dan organisasi pembelajaran.
\end{abstract}

\section{INTRODUCTION}

The security of a country from external threats and rebellion against the state at sea is determined by the strength and alertness of Indonesian Navy soldiers (Anand, 2020). The success of carrying out the task of state security at sea is determined by the professionalism of the Navy's soldiers and the sophistication of equipment, weaponry, and the marine Defense System (Alutsista) (Sari \& IP, 2017). Navy personnel's readiness and success in the field are first determined by the success of educational institutions within the Navy in educating and training cadets and soldiers of the Navy (Varpio et al., 2021). The educational institution of the Navy as a Candradimuka crater for sea-level soldiers must have educators who have characters including knowledge of the subject,

\footnotetext{
${ }^{1}$ Universitas Pertahanan Republik Indonesia

Email: anszaini@gmail.com
}

Received: November 29, 2021; Received in revised form: December 21, 2021; Accepted: December 25, 2021; Available online: December 31, 2021. This is an open access article under a Creative Commons Attribution-NonCommercial-ShareAlike 4.o International License. 
attitude, leadership ability, dan knowledge of teaching techniques (Hartzell et al., 2017). It is necessary to have quality standards for educators which include particular requirements to become naval academy educators, a conceptual teaching and learning process according to the dynamics of the development of educational technology, as well as carrying out quality learning evaluations to produce quality Naval Academy graduates (Sinakou et al., 2019).

The Naval Academy Organic and Non-Organic Educators Meeting were held to gather information from the educators, particularly about the challenges they face in the classroom (Sodiq et al., 2019). According to those in attendance, educators face a variety of challenges, including those relating to their character and those related to their technical skills and knowledge (Maclntyre et al., 2019). Teachers must be committed to their work. A strong sense of responsibility and self-discipline is seen as a motivating factor in completing the task (Anggraini, 2020). Despite encountering various difficulties, someone who persists in completing the task with diligence, tenacity, hard work, and practice. Because the person has to put their desires aside in order to complete the task, this role encourages someone to persevere and be tenacious even when faced with numerous obstacles. A person's ability to learn can be enhanced by their dedication to a task (Pianyta, 2017).

Some researchers have conducted studies on the dedication of educators. Altun (2017) looked at the impact of teacher commitment on student achievement in a classroom context. A recent study by Al-Mahdy et al (2018) found that principal instructional leadership and collective teacher efficacy both contribute to teacher commitment. Cansoy (2020) found that it is a mediator between instructional leadership and teacher loyalty when it comes to teacher efficacy. When it comes to increasing teacher commitment, Khumalo (2019) examines the role of transformational school leadership. No one has looked at how the Indonesian Naval Academy's academic culture and coaching system influence task commitment for the first time. Work motivation, personality, selfdevelopment, organizational culture, leadership, and coaching system, as well as rules and procedures, academic norms and values developed in the classroom (academic culture), the freedom to access a variety of information, and the learning organization's resources for self-improvement, are all discussed in this study.

\section{METHODS}

The purpose of this study was to examine the relationship between task commitment, coaching system, learning organization, and academic culture; learning system and organization of learners toward academic culture; and learning organization development system. Path analysis and survey methods are employed in this research. Exogenous variables (independent/intervening variables) included $\mathrm{X} 1=$ coaching system, $\mathrm{X}_{2}=$ learning organization, and $\mathrm{X}_{3}=$ academic culture, while endogenous variables (dependent variables) included $\mathrm{Y}=$ task commitment.

Each of the 150 students in the Indonesian Navy's educational institutions served as both the intended audience and a viable research sample in this study. A total of 60 people, 20 from the Naval Academy, 28 from Kombagdikal, and 12 from Seskoal were chosen at random from a pool of $40 \%$ of the population. A variety of methods for analyzing the data are discussed, including descriptive statistics, inferential statistics, and testing the assumptions made during the analysis. According to the SPSS-22 program, a frequency distribution table and histogram can be used to present data analysis in descriptive statistics.

\section{FINDINGS AND DISCUSSION}

\section{Normality test}

The analysis requirement test is a normality test using the Liliefors-test method using an estimated error. Test criteria by comparing $L_{\text {count }}$ and $L_{\text {table }}$ for the significance level $\alpha=0.05$. The summary of normality tests for all research variables is stated in the table 1. 
Table 1. Summary of Normality Test Calculation Results

\begin{tabular}{ccccccc}
\hline \multirow{2}{*}{ Number } & \multirow{2}{*}{$\begin{array}{c}\text { Regression } \\
\text { Estimate Error }\end{array}$} & $\mathrm{n}$ & $\mathrm{L}_{\text {count }}$ & \multicolumn{2}{c}{$\mathrm{L}_{\text {table }}$} & \\
\cline { 5 - 6 } & & & $\alpha=5 \%$ & $\alpha=1 \%$ & Information \\
\hline 1 & Y over $\mathrm{X}_{1}$ & 52 & 0,0854 & 0,1229 & 0,1132 & Normal \\
2 & ${\text { Y over } \mathrm{X}_{2}}$ & 52 & 0,1138 & 0,1229 & 0,1132 & Normal \\
3 & ${\text { Y over } \mathrm{X}_{3}}$ & 52 & 0,0717 & 0,1229 & 0,1132 & Normal \\
4 & $\mathrm{X}_{3}$ over $\mathrm{X}_{1}$ & 52 & 0,0833 & 0,1229 & 0,1132 & Normal \\
5 & $\mathrm{X}_{3}$ over $\mathrm{X}_{2}$ & 52 & 0,0670 & 0,1229 & 0,1132 & Normal \\
6 & $\mathrm{X}_{2}$ over $\mathrm{X}_{1}$ & 52 & 0,0882 & 0,1229 & 0,1132 & Normal \\
\hline
\end{tabular}

2. Test of Linearity and Significance of Regression

After the data normality test, the second data analysis requirement requirement is the regression linearity and significance test. The summary of the linearity test and regression significance is as follows:

Table 2. Summary of Significance Test Results and Regression Linearity Test

\begin{tabular}{|c|c|c|c|c|c|c|c|}
\hline \multirow{3}{*}{$\underset{\mathrm{n}}{\text { Regressio }}$} & \multirow{3}{*}{ Equality } & \multicolumn{3}{|c|}{ Significance Test } & \multicolumn{3}{|c|}{ Linearity Test } \\
\hline & & \multirow{2}{*}{$\mathrm{F}_{\text {count }}$} & \multicolumn{2}{|c|}{$\mathrm{F}_{\text {table }}$} & \multirow{2}{*}{$\mathrm{F}_{\text {count }}$} & \multicolumn{2}{|c|}{$F_{\text {table }}$} \\
\hline & & & 0,05 & 0,01 & & 0,05 & 0,01 \\
\hline$Y$ to $\mathrm{X}_{1}$ & $Y=55,796+0,309 X_{1}$ & $11,87^{* *}$ & 4,03 & 7,17 & $0,61^{\mathrm{ns}}$ & 1,97 & 2,63 \\
\hline$Y$ to $\mathrm{X}_{2}$ & $Y=46,321+0,281 X_{2}$ & $13,17 * *$ & 4,03 & 7,17 & $0,69^{\text {ns }}$ & 1,97 & 2,63 \\
\hline $\mathrm{Y}$ to $\mathrm{X}_{3}$ & $\mathrm{Y}=24,351+0,277 \mathrm{X}_{3}$ & $6,22 * *$ & 4,03 & 7,17 & $0,50^{\text {ns }}$ & 1,97 & 2,63 \\
\hline $\mathrm{X}_{3}$ to $\mathrm{X}_{1}$ & $X_{3}=191,796+0,250 X_{1}$ & $4,96 * *$ & 4,03 & 7,17 & $0,07^{\mathrm{ns}}$ & 1,97 & 2,63 \\
\hline $\mathrm{X}_{3}$ to $\mathrm{X}_{2}$ & $X_{3}=164,953+0,371 X_{2}$ & $16,92 * *$ & 4,03 & 7,17 & $0,96^{\mathrm{ns}}$ & 1,97 & 2,63 \\
\hline $\mathrm{X}_{2}$ to $\mathrm{X}_{1}$ & $X_{2}=88.596+0.496 X_{1}$ & $11,50 * *$ & 4,03 & 7,17 & $1,89^{\text {ns }}$ & 1,97 & 2,63 \\
\hline
\end{tabular}

Explanation:

** : Very significant

* $\quad$ : Significant

ns : Non significant (linear regression)

Reading the table above, it is found that $F_{\text {count }}=11.87$ is greater than the value of $F_{\text {table }}=7.17$ at $\alpha=0.01$. Because $F_{\text {count }}>F_{\text {table, }}$, the regression is stated to be very significant. For the linearity test, $\mathrm{F}_{\text {count }}=0.61$ is smaller than $\mathrm{F}_{\text {table }}=1.97$ at $=0.05$. Because $\mathrm{F}_{\text {count }}<\mathrm{F}_{\text {table }}$, the regression of X2 over X1 is linear. Based on the significance test and regression linearity above, the path $\mathrm{X} 2$ over $\mathrm{X} 1$ in the Research Hypothetical Model can be maintained for further analysis of the path coefficients.

\section{Model Testing}

Based on the causal model formed theoretically, a path analysis diagram will be obtained, and then the coefficient value of each path will be calculated. For this reason, hypothesis testing was carried out by testing the significance of the path coefficients of each correlation coefficient between exogenous variables and endogenous variables. The results of the calculation of the regression coefficient can be seen in table 3 .

Table 3. Summary of Correlation Coefficients

\begin{tabular}{ccccc}
\hline & $\mathrm{X}_{1}$ & $\mathrm{X}_{2}$ & $\mathrm{X}_{3}$ & $\mathrm{Y}$ \\
\hline $\mathrm{X}_{1}$ & 1 & 0,4961 & 0,2950 & 0,4379 \\
$\mathrm{X}_{2}$ & 0,4961 & 1 & 0,5023 & 0,4566 \\
$\mathrm{X}_{3}$ & 0,2950 & 0,5023 & 1 & 0,3326 \\
$\mathrm{Y}$ & 0,4379 & 0,2950 & 0,3326 & 1 \\
\hline
\end{tabular}


The path coefficient is obtained by inserting the regression coefficient into the path equation and then testing it with the t-test.

\section{Hypothesis test}

By the results of the calculation of the path coefficients with the help of the SPSS Program, for each substructure, the path coefficients are obtained as stated in the table 4 .

Table 4. Direct Effects Between Variables

\begin{tabular}{cccccccc}
\hline No & $\begin{array}{c}\text { Direct } \\
\text { Influence }\end{array}$ & $\begin{array}{c}\text { Path } \\
\text { Coefficient }\end{array}$ & dk & $\mathbf{t}_{\text {count }}$ & \multicolumn{3}{c}{$\mathbf{t}_{\text {table }}$} \\
\hline 1 & $\mathrm{X}_{1}$ to $\mathrm{Y}$ & 0,28 & 50 & $2,10^{*}$ & 1,68 & 2,01 & 2,63 \\
2 & $\mathrm{X}_{2}$ to $\mathrm{Y}$ & 0,28 & 50 & $1,98^{\circ}$ & 1,68 & 2,01 & 2,63 \\
3 & $\mathrm{X}_{3}$ to $\mathrm{Y}$ & 0,10 & $5^{0}$ & 0,76 & 1,68 & 2,01 & 2,63 \\
4 & $\mathrm{X}_{1}$ to $\mathrm{X}_{3}$ & 0,10 & $5^{0}$ & 0,71 & 1,68 & 2,01 & 2,63 \\
5 & $\mathrm{X}_{2}$ to $\mathrm{X}_{3}$ & 0,46 & $5^{0}$ & $3,38^{* *}$ & 1,68 & 2,01 & 2,63 \\
6 & $\mathrm{X}_{1}$ to $\mathrm{X}_{2}$ & 0,56 & 50 & $3,39^{* *}$ & 1,68 & 2,01 & 2,63 \\
\hline
\end{tabular}

$$
\begin{array}{ll}
\mathrm{o} & =\text { moderate }\left(\mathrm{t}_{\text {count }}>\mathrm{t}_{\text {table }} \text { on } \alpha=0,10\right) \\
* & =\text { significant }\left(\mathrm{t}_{\text {count }}>\mathrm{t}_{\text {table }} \text { on } \alpha=0,05\right) \\
* * & =\text { very significant }\left(\mathrm{t}_{\text {count }}>\mathrm{t}_{\text {table }} \text { on } \alpha=0,01\right)
\end{array}
$$

The research found two paths that are not significant and four are significant. The explanation of the results of the analysis will be explained as below.

\section{Insignificant path}

The finding of an insignificant path is the influence between the Coaching System on Academic Culture and the Effect of Academic Culture on Task Commitment. Then it was found that the Learning Organization did not strongly influence increasing Task Commitment. Based on Ivancevich's statement, the orientation program is part of the coaching system and part of organizational culture formation. This means that the coaching system affects the organizational culture. On the other hand, academic culture is part of the organizational culture in the university environment, which the coaching system should influence. However, because the effect is not significant (there is indeed an effect, but it is not significant), the $\mathrm{X}$ variable is more dominant towards academic culture than the coaching system.

\section{Significant Path}

\section{a) Positive Direct Effect of the Coaching System $\left(X_{1}\right)$ on Task Commitment (Y)}

The results of the path analysis on the direct influence of the Coaching System $\left(\mathrm{X}_{1}\right)$ on Task Commitment (Y), where the correlation coefficient value of $\mathrm{r}_{\mathrm{yy}}=0.44$ and the path coefficient value of $\beta_{\mathrm{y} 1}=0.28$, means that there is a direct positive influence between the Coaching System $\left(\mathrm{X}_{1}\right)$ towards Task Commitment (Y).

A direct influence between the Coaching System on Task Commitment shows that the Coaching System can increase Task Commitment. With the increase or intensity, or the more influential the Coaching System, it will strongly influence the Commitment of the Tasks. On the other hand, the more ineffective the Coaching System is, will result in a weakening of Task Commitment. It is in line with Jackson (2019) research which found that capacity building, which is also part of the Coaching System, tends to work more effectively to be happier with their work. That is, people who get good coaching will love their work. Thus, the findings of this study are proof of a hypothesis that has received legitimacy from experts. 


\section{b) Positive Direct Effect of Learning Organization $\left(\mathrm{X}_{2}\right)$ on Task Commitment $(\mathrm{Y})$}

The results of the path analysis on the direct influence of the Learning Organization $\left(\mathrm{X}_{2}\right)$ on Task Commitment (Y), where the correlation coefficient value of $r_{2 y}=0.45$ and the path coefficient value of $\beta_{\mathrm{y} 2}=0.26$, gives a meaning that there is a direct positive influence between Learning Organizations $\left(\mathrm{X}_{2}\right)$ on Task Commitment $(\mathrm{Y})$. A direct influence between Learning Organizations on Task Commitment shows that Learning Organizations can increase Task Commitment. With the increase of the effectiveness of the Learning Organization, it will have a strong influence on its Task Commitment. On the other hand, the more ineffective the Learning Organization, the weaker the Task Commitment will be. The findings of this study are supported by Spanuth (2017), who say that learning has a weak positive effect on commitment. This statement helps the study's results, which are stronger than the statement above. Learning organization can encourage employees to form complex mental models and develop a sense of self-control by providing them with opportunities to take more responsibility for their decisions.

\section{c) Positive Direct Influence of Learning Organizations $\left(X_{2}\right)$ on Academic Culture} $\left(\mathbf{X}_{3}\right)$

The results of the path analysis on the direct influence of the Learning Organization $\left(\mathrm{X}_{2}\right)$ on Academic Culture $\left(\mathrm{X}_{3}\right)$, where the correlation coefficient value of $\mathrm{r}_{23}=0.50$ and the path coefficient value of $\beta_{32}=0.46$, means that there is a direct positive influence between Learning Organizations $\left(\mathrm{X}_{2}\right)$ towards Academic Culture $\left(\mathrm{X}_{3}\right)$. The existence of a direct influence between Learning Organizations on Academic Culture shows that Learning Organizations can improve Academic Culture. Increasing or more effective Learning Organizations will affect the increase in Academic Culture. On the other hand, the more ineffective the Learning Organization, the weaker the Academic Culture will be. Leonardi (2021) argues that a learning organization can encourage employees to form complex mental models and develop a sense of self-control by providing them with opportunities to be more responsible.

The development of mental models and opportunities to make more responsible decisions are part of the formation of academic culture. This means that the learning organization has a direct effect on academic culture. Thus, the results of the study, which state that learning organizations have a direct and positive effect on academic culture, are supported by experts.

\section{d) Positive Direct Effects of the Coaching System $\left(X_{1}\right)$ on Learning Organizations $\left(\mathbf{X}_{\mathbf{2}}\right)$}

The results of the path analysis on the direct influence of the Coaching System $\left(\mathrm{X}_{1}\right)$ on the Learning Organization (X2), where the correlation coefficient value is $r_{12}=0.50$, and the path coefficient value is $\beta_{21}=0.43$, gives a meaning that there is a direct positive influence between the Coaching System $\left(\mathrm{X}_{1}\right)$ on the Learning Organization $\left(\mathrm{X}_{2}\right)$. The existence of a direct influence between the Coaching System on the Learning Organization is supported by experts. According to Page \& Prescott (2005), their research results show that training is related to skills and abilities related to current work. Training is also an orientation and assistance to employees to master skills and abilities.

Activities related to improving the abilities and skills of employees are part of improving personal mastery as part of a learning organization. Uhl-Bien \& Arena (2018) argues that learning in organizations such as Xerox, General Electric, and Pittsburgh Plate Glass (PPG) has traced the direction of organizational learning in 3 stages; (1) cognitive - members are introduced to new ideas, develop their knowledge, and begin to think differently; (2) behaviour - employees begin to change their behaviour and (3) improve performance - change behaviour that leads to improved measurable results.

\section{CONCLUSION}

Exogenous variables directly and positively impact endogenous variables, as shown by the research presented above. The conclusion drawn from this is that Coaching Systems and Learning Organizations positively impact Task Commitment. Academic Culture, on the other hand, has no positive impact on the level of commitment to a task. On the other hand, the Coaching System does 
not positively affect Academic Culture, while Learning Organizations do. Finally, it can be concluded that the Coaching System has a direct positive impact. This study is based on numbers. The theory of supporting factors for task commitment in education can be described in greater detail for future research.

\section{REFERENCES}

Al-Mahdy, Y. E. H., Emam, M. M., \& Hallinger, P. (2018). Assessing the contribution of principal instructional leadership and collective teacher efficacy to teacher commitment in Oman. Teaching and Teacher Education, 69, 191-201.

Altun, M. (2017). The effects of teacher commitment on student achievement: A case study in Iraq. International Journal of Academic Research in Business and Social Sciences, 7(11), 417426.

Anggraini, V., \& Neviyarni, S. (2020). The Task Commitment on Student. Journal of Counseling, Education and Society, 1(1), 13-16.

Cansoy, R., Parlar, H., \& Polatcan, M. (2020). Collective teacher efficacy as a mediator in the relationship between instructional leadership and teacher commitment. International journal of leadership in education, 1-19.

Khumalo, S. S. (2019). The role of transformational school leadership in promoting teacher commitment: An antecedent for sustainable development in South Africa. Discourse and Communication for Sustainable Education, 10(2), 22-32.

Leonardi, P. M., Woo, D., \& Barley, W. C. (2021). On the making of crystal balls: Five lessons about simulation modeling and the organization of work. Information and Organization, 31(1), 100339.

MacIntyre, P. D., Gregersen, T., \& Mercer, S. (2019). Setting an agenda for positive psychology in SLA: Theory, practice, and research. The Modern Language Journal, 103(1), 262-274.

Page, S., \& Prescott, T. L. (2005). Performance Management and Customer Satisfaction: Constructing a Conceptual Model for Enquiry. In ECRM2005-Proceedings of the 4th European Conference on Research Methods: ECRM2005 (p. 371). Academic Conferences Limited.

Pianyta, A. (2017). Pengaruh kedisiplinan dan task commitment terhadap prestasi belajar matematika. JKPM (Jurnal Kajian Pendidikan Matematika), 2(1), 80-92.

Sari, S., \& IP, S. (2017). Indonesia Defense Strategy Dealing with Shift the United States Strategy in Asia Pacific. International Journal of Social Sciences, 6o(1).

Sinakou, E., Donche, V., Boeve-de Pauw, J., \& Van Petegem, P. (2019). Designing powerful learning environments in education for sustainable development: A conceptual framework. Sustainability, 11(21), 5994.

Sodiq, A., Baloch, A. A., Khan, S. A., Sezer, N., Mahmoud, S., Jama, M., \& Abdelaal, A. (2019). Towards modern sustainable cities: Review of sustainability principles and trends. Journal of Cleaner Production, 227, 972-1001.

Spanuth, T., \& Wald, A. (2017). Understanding the antecedents of organizational commitment in the context of temporary organizations: An empirical study. Scandinavian Journal of Management, 33(3), 129-138.

Uhl-Bien, M., \& Arena, M. (2018). Leadership for organizational adaptability: A theoretical synthesis and integrative framework. The Leadership Quarterly, 29(1), 89-104.

Varpio, L., Bader-Larsen, K. S., Durning, S. J., Artino, A., Hamwey, M. K., Cruthirds, D. F., \& Meyer, H. S. (2021). Military interprofessional healthcare teams: identifying the characteristics that support success. Military Medicine, 186(Supplement_3), 1-6. 
Al- Ishlah: Jurnal Pendidikan, December 2021, 13 (3) Pages 2529-2534 A Study on Task Commitment in Coaching Systems, Academic Culture, and Learning Organizations 